\title{
UPAYA PEREMAJAAN DAN PENYERAPAN LOGAM MINYAK GORENG BEKAS INDUSTRI MAKANAN TRADISIONAL DENGAN MEMANFAATKAN BIOADSORBEN TANDAN KOSONG KELAPA SAWIT (TKKS)
}

\author{
THE EFFORTS of RENEWING AND ABSORBING of METAL ON USED \\ COOKING OIL frOM TRADITIONAL FOOD INDUSTRIES THROUGH \\ APPLICATION of BIOADSORBENT OF EMPTY FRUIT BUNCH OF \\ PALM
}

\author{
Susi Desminarti dan Edi Joniarta \\ Jurusan Teknologi Pertanian Politeknik Pertanian Negeri Payakumbuh \\ Tanjung Pati Sumbar \\ isusdesmiyati@yahoo.com
}

\begin{abstract}
The research has been carried out in the Processing and Chemistry Laboratory of Politeknik Pertanian Negeri Payakumbuh and Post Harvest Laboratory in Bogor since July until November 2006. The research objectives was to prolong the using time of used cooking oil on food industries through applying the empty fruit bunch of palm bioadsorbent. The optimum condition of TKKS applied were $125 \mu \mathrm{m}$ size and 5\% bioadsorben from the weight of oil (Desminarti dan Rahzarni, 2004). The prolonging of cooking oil application can be done through refining used cooking oil so that the part of bad cooking oil can be lremoved. Statistical design used in this research was Completely Randomized Design with four treatments dan three replications. If the result was significant it will be followed by DMRT test on 5\% significant level. Based on the experiment could be concluded that that four times titration could produced the oil based on SNI criterya in the relation to the water content $(0.23 \%)$, peroxide value $(0.82 \%)$ and free fatty acid value $(0.23 \%)$ and it could also decrease Fe content from 76 $\mathrm{ppm}$ to $22 \mathrm{ppm}, \mathrm{Cu}$ from $1.2 \mathrm{ppm}$ to $0.40 \mathrm{ppm}$ and Non Urea Adduct Forming (NAF) from $126 \mathrm{ppm}$ to $102 \mathrm{ppm}$. The bioadsorbent sorption content on water varied from $78 \%$ to $80 \%$; peroxide value from 14.71 to $59.80 \%$, free fatty acid from 55.61 to $89.25 \%$, Fe from 68.42 to $71.05 \%$, Cu from $5 \%$ to $60 \%$ and NAF from 17.46 to $19.05 \%$.
\end{abstract}

Key words: cooking oil, TKKS, renewing, absorbing

\begin{abstract}
ABSTRAK
Penelitian dilaksanakan di Laboratorium Pengolahan dan Kimia Polteknik Pertanian Negeri Payakumbuh dan Laboratorium Balai Besar Pasca Panen Bogor dari bulan Juli sampai November 2006. Tujuan penelitian ini adalah memperpanjang masa pakai minyak goreng pada industri makanan dengan memanfaatkan bioadsorben tandan kosong kelapa sawit (TKKS). Kondisi optimum TKKS yang digunakan adalah ukuran $125 \mu \mathrm{m}$ dan jumlah bioadsorben 5\% dari berat minyak (Desminarti dan Rahzarni, 2004). Perpanjangan umur pemakaian minyak goreng ini dilakukan dengan cara memurnikan kembali minyak goreng yang telah digunakan sehingga bagian minyak goreng yang telah rusak dapat dihilangkan. Rancangan statistik dalam penelitian ini menggunakan rancangan acak lengkap (RAL) dengan empat perlakuan dan tiga ulangan. Bila ternyata berbeda nyata akan dilanjutkan dengan uji DMRT pada taraf kesalahan 5\%. Berdasarkan dari penelitian yang telah dilaksanakan dapat diambil kesimpulan bahwa penyaringan sebanyak empat kali telah dapat menghasilkan minyak yang telah memenuhi SNI dari segi kadar air $(0.23 \%)$, bilangan peroksida $(0.82 \%)$ dan bilangan asam lemak bebas $(0.23 \%)$
\end{abstract}


serta dapat menurunkan kandungan logam Fe dari 76 ppm menjadi 22 ppm, Cu dari 1,2 ppm menjadi 0,40 ppm dan Non Urea Adduct Forming (NAF) dari 126 ppm menjadi 102 ppm. Serapan bioadsorben terhadap kandungan kadar air berkisar $78 \%$ sampai $80 \%$, bilangan peroksida $14,71 \%$ sampai 59,80\%, asam lemak bebas dari $55,61 \%$ sampai 89,25\%, logam Fe dari 68,42\% sampai 71,05\%, logam Cu dari 5\% sampai 60\% serta NAF dari $17,46 \%$ sampai $19,05 \%$.

Kata kunci: minyak goreng, TKKS, peremajaan, penyerapan

\section{PENDAHULUAN}

Masyarakat pada umumnya menggunakan minyak goreng untuk mengolah bahan pangan. Berbagai industri pangan dan rumah tangga menggunakan minyak goreng sebagai media untuk menggoreng, memberikan aroma dan menambah nilai gizi makanan. Hasil pengamatan pada beberapa industri menunjukkan minyak yang sudah digunakan untuk menggoreng (minyak jelantah) tidak langsung dibuang, melainkan digunakan secara berulang-ulang dengan tujuan untuk menghemat biaya, terutama bagi industri yang menggunakan minyak dalam jumlah besar. Minyak yang digunakan ini kadang-kadang berwarna kehitaman dan berubah aromanya. Hal biasa yang dilakukan adalah menambah minyak goreng baru sebanyak 12.5 - 15\% kedalam minyak goreng lama setiap hari.

Pemanasan minyak pada suhu yang sangat tinggi dan berulang-ulang dapat menghasilkan isomer asam lemak trans yang banyak dikaitkan dengan gangguan kesehatan. Berbagai reaksi kimia akan terjadi diantaranya hidrolisis, oksidasi, isomerisasi, polimerisasi yang akan mempengaruhi rupa, cita rasa maupun nilai gizinya. Salah satu senyawa toksik hasil dari reaksi oksidasi polimerisasi yang terjadi pada minyak selama penggorengan adalah senyawa NAF (Non Urea Adduct Forming). NAF terdiri dari derifat asam lemak yang membentuk kompleks dengan asam lemak (Fristone et al., 1961 in Liener, 1980). NAF ternyata bersifat karsinogenik terhadap tikus yang memakannya sehingga dapat menginduksi terjadinya tumor dan kanker dimasa datang. Selain senyawa toksik, minyak jelantah juga mengandung logam-logam berat seperti kadmium, besi, dan krom yang berasal dari proses pengolahan dan peralatan yang digunakan terbuat dari logam (Marlina, 1997).
Tingginya biaya untuk minyak goreng di industri-industri maka diperlukan metoda untuk memperpanjang umur pakai minyak goreng. Sampai saat ini telah banyak dilakukan penelitian untuk memperpanjang umur pakai minyak goreng, salah satunya menggunakan adsorben. Adsorben yang umum digunakan berupa persenyawaan kimia seperti arang aktif, bentonit, zeolit dan alumina dimana harganya relatif mahal (Winarno, 1999).

Mengingat mahalnya harga adsorben kimia ini, maka akhir-akhir ini dikembangkan bioadsorben sebagai penyerap senyawa organik dan anorganik yang lebih murah dibandingkan dengan arang aktif dan lain-lain. Beberapa bioadsorben telah diuji kemampuannya untuk menyerap senyawa anorganik (logam berat) seperti hasil penelitian Rahzarni (2003) menunjukkan bahwa tempurung kemiri juga dapat menyerap krom sebanyak 95.10\% dan kadmium sebanyak $86.07 \%$ dalam air limbah. Namun aplikasi bioadsorben pada proses pengolahan pangan masih belum banyak diteliti.

Penggunaan bioadsorben pada produk pangan baru dilakukan oleh Desminarti dan Rahzarni (2004), ternyata bioadsorben dari tandan kosong kelapa sawit (TKKS) dapat menyerap warna dan logam $\mathrm{Fe}$ dan $\mathrm{Cu}$ minyak CPO. Biosorben TKKS dapat menyerap Fe sebanyak $71 \%$ dan $\mathrm{Cu}$ sebanyak $12 \%$ pada suhu $80{ }^{\circ} \mathrm{C}$. TKKS merupakan limbah pada terbesar pada industri kelapa sawit, yaitu sebanyak $25-35 \%$ (Said, 1996).

Tujuan penelitian ini adalah memperpanjang masa pakai minyak goreng pada industri makanan dengan memanfaatkan bioadsorben TKKS. Hasil penelitian ini dapat dimanfaatkan untuk membantu program pemerintah mengatasi kebutuhan minyak goreng pada industri dengan cara memperpanjang umur pakai minyak goreng sebelum dibuang 
karena telah terjadi penurunan mutu minyak. Selain itu dapat mengurangi resiko dari reaksi oksidasi dan polimerisasi berupa senyawa karsinogenik yang membahayakan kesehatan masyarakat serta diharapkan dapat mendorong tumbuhnya industri bioadsorben dari tandan kosong kelapa sawit dimasa datang.

\section{METODE PENELITIAN}

Penelitian dilaksanakan di Laboratorium Teknologi Pangan dan Kimia Politeknik Pertanian Negeri Payakumbuh, dan Laboratorium Pascapanen Balai Penelitian Pasca Panen Pertanian Bogor. Penelitian ini dilaksanakan selama enam bulan dari Juli sampai dengan bulan Desember 2006.

Bahan yang digunakan dalam penelitian ini adalah tandan kosong kelapa sawit (TKKS) dan minyak goreng bekas setelah dipakai selama 8 hari untuk menggoreng yang diperoleh dari industri keripik di Payakumbuh. Bahan kimia untuk analisis terdiri dari HNO3, etanol, heksan, aseton, standar beta karoten, akuades, kertas saring whatman, $\mathrm{NaOH}$, asam asetat, larutan buffer, dan larutan standar logam.

Penelitian ini menggunakan rancangan acak lengkap (RAL) dengan 4 perlakuan dan 3 ulangan. Bila ternyata berbeda nyata akan dilanjutkan dengan uji DMRT pada taraf kesalahan $5 \%$. Perlakuan pada penelitian ini adalah: 1) Perlakuan A (penyaringan satu kali), 2) Perlakuan B (penyaringan dua kali), 3) Perlakuan C (penyaringan tiga kali), dan Perlakuan D (penyaringan empat kali).

Tandan kosong kelapa sawit (TKKS) terlebih dahulu dicuci, kemudian dikeringkan, dihancurkan dan digiling untuk mereduksi ukuran partikel. Partikel diayak dengan saringan ukuran partikel $125 \mu \mathrm{m}$. Hasil saringan direndam dengan HNO3 1\% selama 3 jam untuk menghilangkan ion logam runut yang terdapat dalam TKKS, dicuci dengan akuades hingga $\mathrm{pH}$ netral, lalu disaring dan dikeringanginkan pada temperatur kamar sehingga didapatkan bioadsorben kering. Bioadsorben yang sudah kering dapat dipakai untuk bahan adsorben minyak goreng industri makanan. Kondisi bioadsorben yang digunakan mengacu pada hasil penelitian Desminarti dan Rahzarni (2004) adalah ukuran partikel $125 \mu \mathrm{m}$ dan berat bioadsorben 5\% dari berat minyak.

Bioadsorben dengan ukuran partikel $125 \mu \mathrm{m}$ ditimbang sebanyak 5\% dari berat minyak. Selanjutnya dimasukkan kedalam kolom yang telah berisi kapas sebanyak $0.5 \mathrm{~g}$. Kolom yang digunakan berukuran $150 \mathrm{~mm}$ x $10 \mathrm{id}$. Kemudian kedalam kolom yang telah berisi bioadsorben dialirkan minyak. Proses ini diulangi sesuai perlakuan. Terhadap minyak goreng bekas dan minyak setelah penyaringan dilakukan analisa sifat fisik dan kimia.

Analisa sifat fisik dan kimia minyak meliputi analisis kadar asam lemak bebas (SNI 01-35551998), bilangan peroksida (SNI 01-3555-1998), kadar air (SNI 01-3555-1998), bilangan iod dianalisa menurut Hanus (AOAC, 1995), kadar logam $\mathrm{Fe}$ dan $\mathrm{Cu}$ dengan spektrofotometer serapan atom (SSA) serta kadar NAF menurut Sahasrabudne and Bhalerao (1963).

\section{HASIL DAN PEMBAHASAN}

\section{Mutu awal minyak jelantah.}

Pada pengujian mutu minyak jelantah awal dilakukan karakterisasi sampel minyak jelantah dengan tujuan untuk mengetahui sifat fisiko-kimia minyak (Tabel 1).

Berdasarkan hasil karakterisasi awal sampel minyak (Tabel 1) menunjukkan bahwa minyak jelantah yang akan diremajakan pada peneltian ini mutunya sangat rendah bila dibandingkan dengan standar SNI. Hal ini dapat dilihat lebih tingginya hasil karakterisasi minyak awal bila dibandingkan dengan SNI sehingga dapat dikatakan bahwa sampel minyak telah mengalami kerusakan yang sangat tinggi. Kerusakan yang terjadi dapat disebabkan oleh proses hidrolisis, oksidasi maupun polimerisasi pada saat menggoreng yang telah dilakukan. Karakterisasi awal minyak jelantah ini ada hubungannya dengan bahan yang digoreng. Minyak awal yang digunakan berasal dari penggorengan keripik industri makanan tradisional. 
Tabel 1. Hasil karakterisasi awal minyak jelantah

\begin{tabular}{lllll}
\hline \hline No & Parameter & Satuan & Hasil & Standar SNI-3555-1998 \\
\hline 1 & Kadar air & $\% \mathrm{~b} \mathrm{~b}^{-1}$ & 1.05 & Maksimum 0.3 \\
2 & Bilangan peroksida & mgek per $100 \mathrm{~g}$ & 2.04 & Maksimum 1.0 \\
3 & Bilangan Iod & $\mathrm{mg} \mathrm{g} \mathrm{01}^{-1}$ & 57.26 & Tidak dipersyaratkan \\
4 & Asam lemak bebas & $\% \mathrm{~b} \mathrm{~b}^{-1}$ & 2.14 & Maksimum 0.3 \\
5 & Logam Fe & $\mathrm{ppm}$ & 76 & Tidak dipersyaratkan \\
6 & Logam Cu & $\mathrm{ppm}$ & 1.2 & Tidak dipersyaratkan \\
7 & NAF & $\mathrm{ppm}$ & 126 & Tidak dipersyaratkan \\
\hline
\end{tabular}

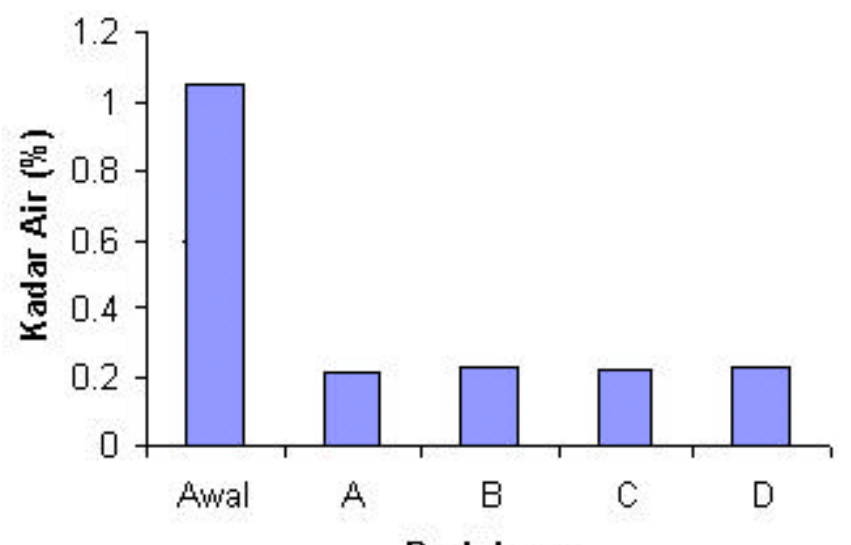

$$
\begin{aligned}
& A=\text { Penyaringan } 1 \mathrm{kali} \\
& B=\text { Penyaringan } 2 \mathrm{kali} \\
& C=\text { Penyaringan } 3 \mathrm{kali} \\
& D=\text { Penyaringan } 4 \mathrm{kali}
\end{aligned}
$$

Perlakuan

Gambar 1. Histogram hubungan antara perlakuan penyaringan minyak jelantah dengan bioadsorben terhadap kadar air minyak.
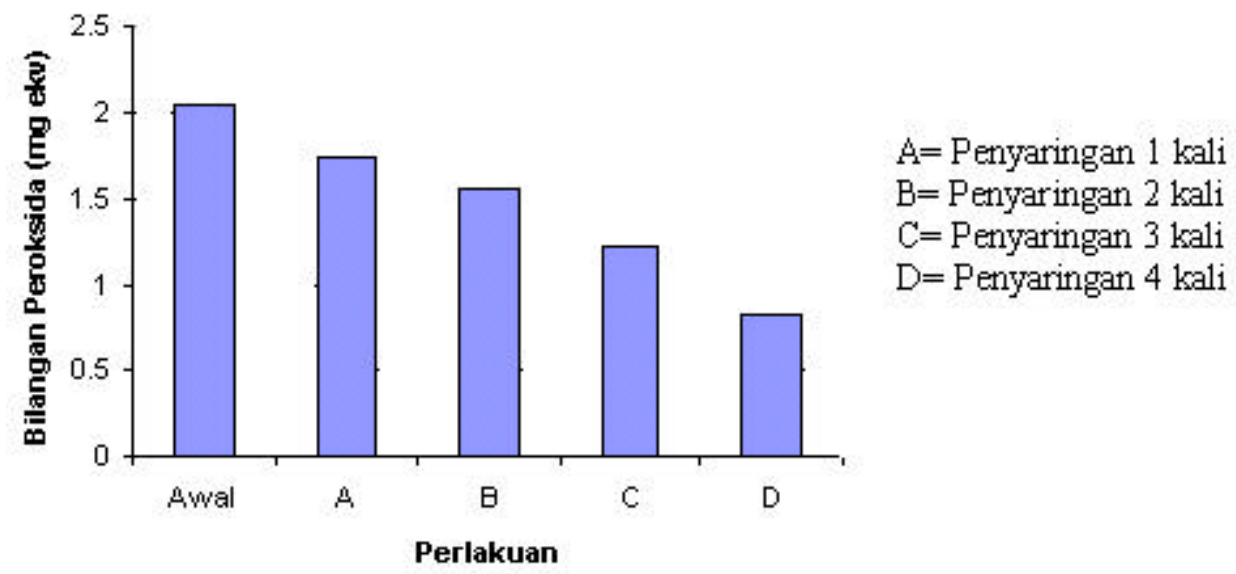

Gambar 2. Histogram hubungan antara perlakuan penyaringan minyak jelantah dengan bioadsorben terhadap nilai bilangan peroksida. 
Peningkatan mutu minyak jelantah setelah penyaringan

Pengujian mutu minyak setelah penyaringan meliputi kadar air, bilangan peroksida, bilangan iod, kadar asam lemak bebas, kadar logam $\mathrm{Fe}$ dan $\mathrm{Cu}$ serta kadar NAF.

\section{Kadar air}

Berdasarkan analisis diketahui bahwa kadar air minyak hasil penyaringan berkisar antara $0,21 \%$ sampai $0.23 \%$. Hasil analisis keragaman menunjukkan bahwa penyaringan berulang berpengaruh nyata terhadap penurunan kadar air.

Perlakuan penyaringan mampu meurunkan kadar air minyak awal (Gambar 1). Turunnya kadar minyak awal dipengaruhi oleh penyerapan air oleh biosorben TKKS. Penyaringan yang berulang tidak menghasilkan penurunan yang signifikan karena telah terjadi penyerapan kadar air minyak awal oleh bioadsorben TKKS pada penyaringan pertama.

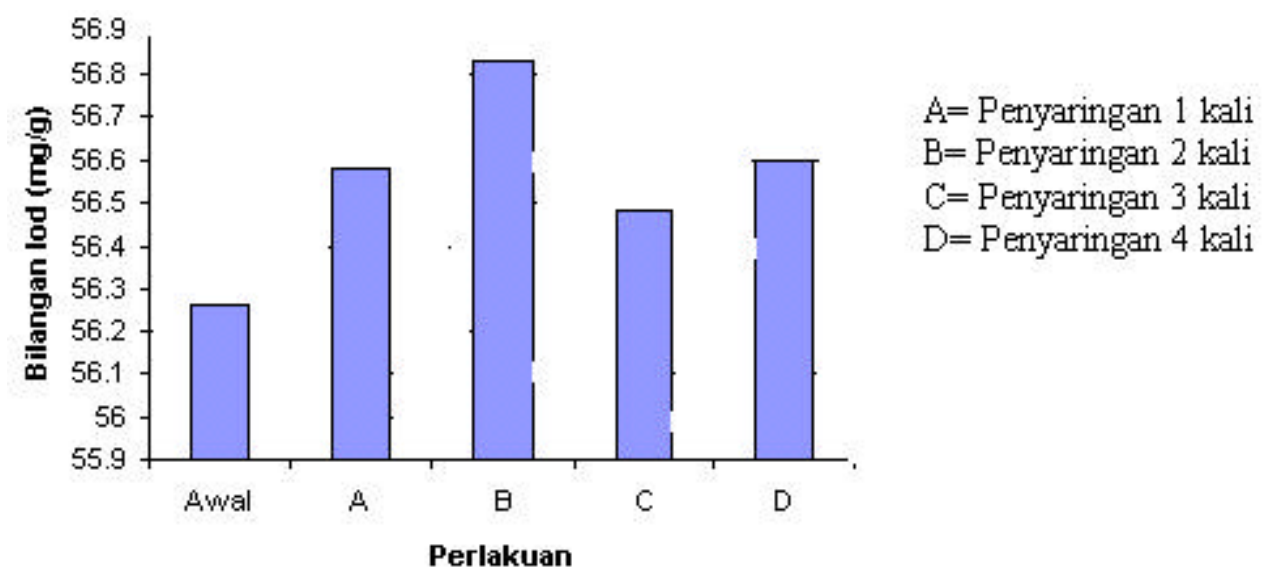

Gambar 3. Histogram hubungan antara perlakuan penyaringan minyak jelantah dengan bioadsorben terhadap nilai bilangan iod.

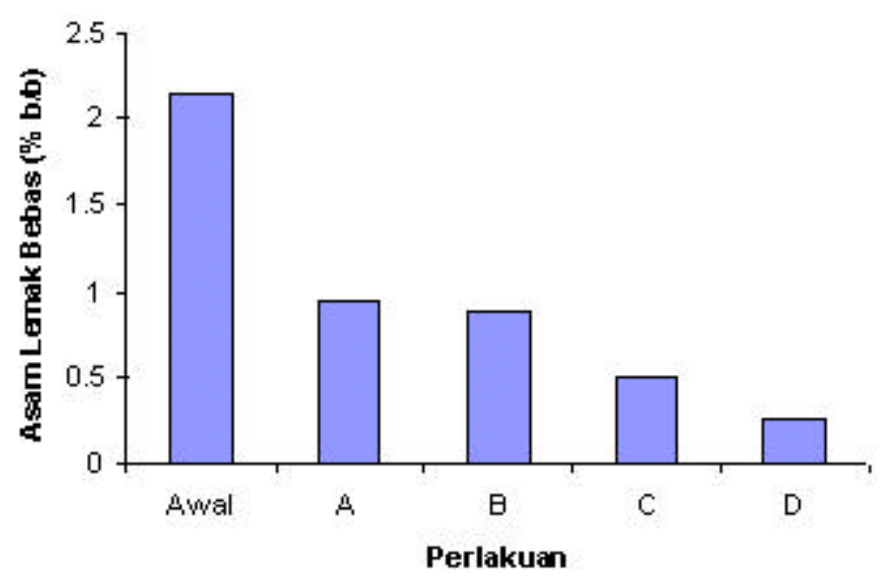

$A=$ Penyaringan $1 \mathrm{kali}$

$\mathrm{B}=$ Penyaringan $2 \mathrm{kali}$

$\mathrm{C}=$ Penyaringan $3 \mathrm{kali}$

$\mathrm{D}=$ Penyaringan $4 \mathrm{kali}$

Gambar 4. Histogram hubungan antara perlakuan penyaringan terhadap nilai bilangan asam lemak bebas. 


\section{Bilangan peroksida}

Pengukuran bilangan peroksida minyak hasil penyaringan berkisar antara 0.82 mgekv per 100 g sampai 1.74 mgekv per 100 g. Hasil analisis keragaman menunjukkan bahwa perlakuan penyaringan berpengaruh nyata terhadap penurunan bilangan peroksida. Sampel minyak awal memiliki nilai bilangan peroksida yang sangat tinggi yaitu 2.04 mgek per 100 g (Gambar 2). Tingginya bilangan peroksida awal menunjukkan bahwa minyak awal telah terjadi kerusakan akibat proses oksidasi sehingga terbentuk peroksida. Proses pembentukan peroksida yang tinggi juga dipercepat oleh adanya kandungan logam di dalam minyak. Logam menrupakan katalis dalam pembentukan peroksida di dalam minyak (Djatmiko dan Ketaren, 1985). Berdasarkan hasil proses penyaringan diketahui perlakuan penyaringan cenderung menurunkan nilai bilangan peroksida antara 1,74 mgekv per $100 \mathrm{~g}$ sampai 0.82 mgekv per $100 \mathrm{~g}$. SNI mensyaratkan nilai bilangan peroksida minyak maksimum 1 mgekv per $100 \mathrm{~g}$. Dengan demikian perlakuan penyaringan minyak sebanyak empat kali telah memenuhi standar SNI minyak.

Penurunan nilai bilangan peroksida berhubungan dengan penurunan kadar asam lemak bebas minyak setelah penyaringan. Hilangnya asam organik rantai pendek setelah penyaringan mengakibatkan bilangan peroksida lebih rendah.

\section{Bilangan Iod}

Hasil pengukuran bilangan iod minyak hasil penyaringan berkisar antara $56.60 \mathrm{mg} \mathrm{g}^{-1}$ sampai $57.26 \mathrm{mg} \mathrm{g}^{-1}$. Analisis keragaman menunjukkan bahwa perlakuan penyaringan berpengaruh tidak nyata terhadap kandungan bilangan iod. Nilai bilangan iod sebelum penyaringan relatif lebih rendah dibandingkan dengan setelah penyaringan (gambar 3). Hal ini berhubungan dengan kandungan logam minyak. Peningkatan bilangan iod hasil penyaringan bukan disebabkan oleh terbentuknya ikatan rangkap baru selama proses penyaringan. Hal ini disebabkan karena hilangnya sejumlah senyawa yang tidak diinginkan selama proses penyaringan minyak seperti senyawasenyawa jenuh hasil penguraian peroksida berupa asam organik rantai pendek dan senyawasenyawa asam lemak bebas dengan ikatan jenuh. Produk polimer dan NAF juga hilang pada saat panyaringan. Senyawa ini diabsorb oleh biosorben TKKS sehingga terjadi kenaikan kandungan bilangan iod setelah penyaringan. Namun kenaikan kandungan bilangan iod setelah penyaringan relatif tidak berbeda dengan kandungan bilangan iod sebelum penyaringan.

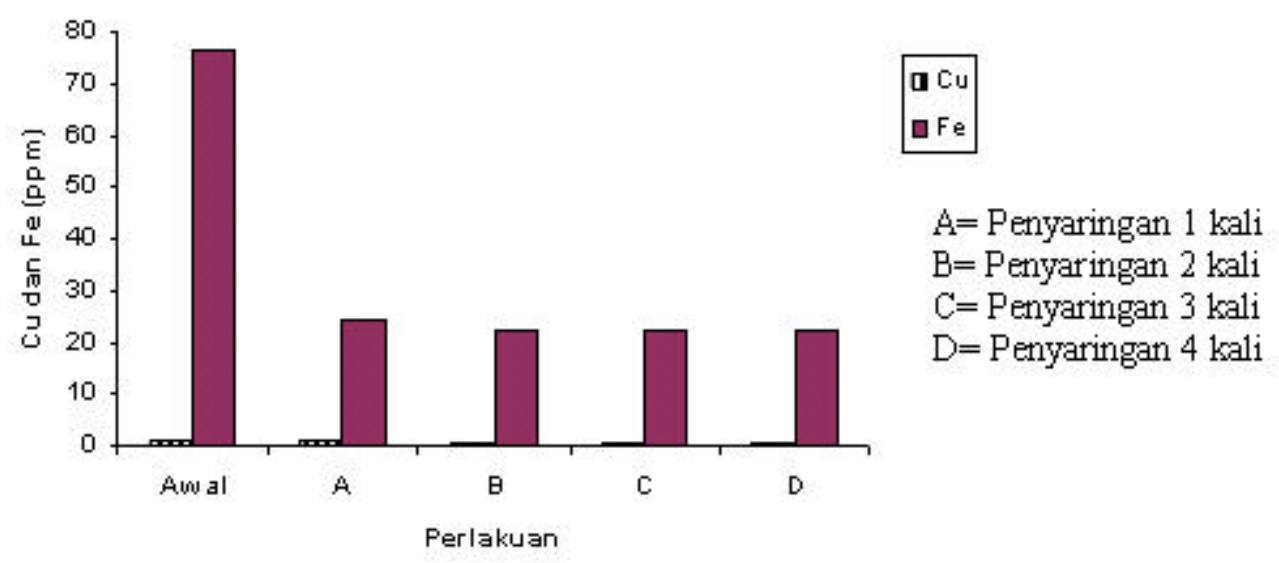

Gambar 5. Histogram hubungan antara perlakuan penyaringan minyak jelantah dengan bioadsorben terhadap nilai kandungan logam $\mathrm{Fe}$ dan $\mathrm{Cu}$. 


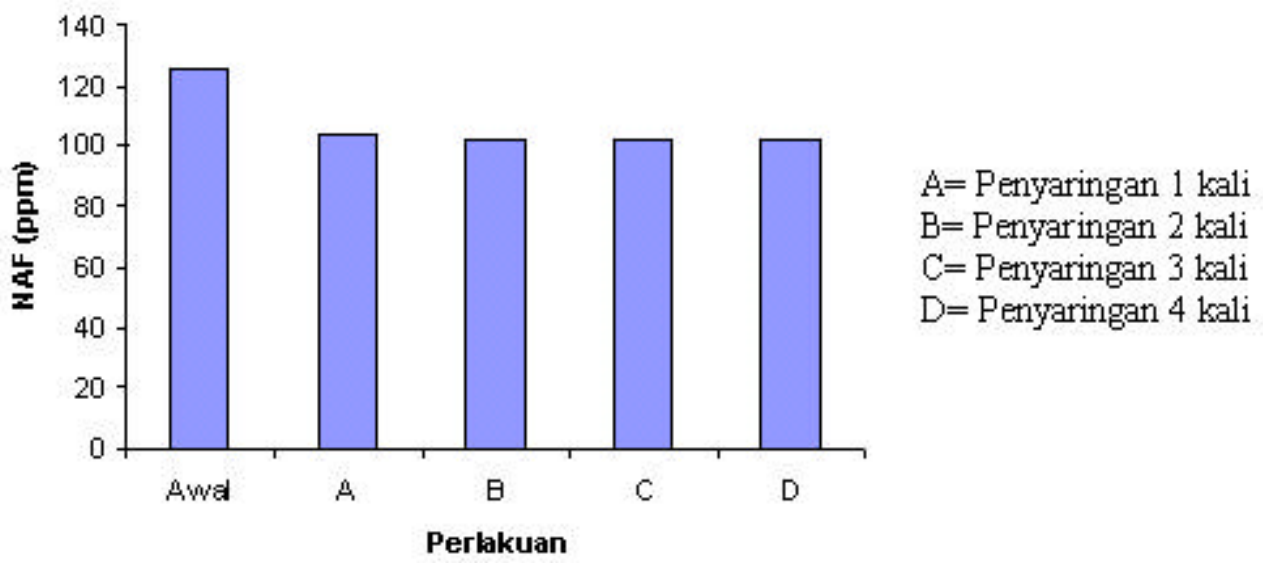

Gambar 6. Histogram hubungan antara perlakuan penyaringan terhdap minyak jelantah dengan biosorben terhadap nilai NAF

\section{Asam lemak bebas}

Berdasarkan hasil pengukuran kadar asam lemak bebas minyak hasil penyaringan berulang berkisar antara $0.23 \% \mathrm{~b} \mathrm{~b}^{-1}$ sampai $0.95 \% \mathrm{~b} \mathrm{~b}^{-1}$. Hasil analisis keragaman menunjukkan bahwa perlakuan penyaringan satu kali dan penyaringan dua kali berbeda tidak nyata tetapi berbeda nyata dengan perlakuan penyaringan tiga kali dan penyaringan empat kali. Kandungan minyak awal relatif tinggi yaitu sebesar $2.14 \%$ (Gambar 4). Tingginya kadar asam lemak bebas minyak awal disebabkan karena tingginya kerusakan minyak selama penggunaan. Terjadinya proses oksidasi dan hidrolisis akan menyebabkan asam lemak bebas minyak meningkat.

Proses penyaringan ternyata mampu menurunkan kandungan asam lemak bebas awal minyak dari $2.14 \%$ menjadi berkisar antara $0.23 \%$ sampai $0.95 \%$. Penyaringan minyak sampai empat kali mengandung asam lemak bebas sebesar $0.23 \%$ dan telah memenuhi standar mutu minyak (SNI minyak maksimum $0.3 \%$ ). Terjadinya penyerapan oleh bioadsorben dipercayai melalui proses adsorbsi yang melibatkan kandungan lignin, selulosa, gugus karboksil dan hiroksi fenol. Dizhbite et al. (1999), lignin merupakan grup polimerfenol multifungsional yang mengandung gugus hidroksil, karboksil, dam karbonil.

\section{Logam Fe dan Cu serta NAF}

Hasil pengukuran kandungan logam $\mathrm{Fe}$ dan $\mathrm{Cu}$ serta NAF minyak hasil penyaringan menunjukkan bahwa nilai kandungan logam Fe dan $\mathrm{Cu}$ minyak hasil penyaringan berulang berkisar antara 22 ppm sampai 24 ppm dan antara 0,5 ppm sampai 1,1 ppm serta kandungan NAF antara 102 ppm dan 104 ppm. Histogram hubungan antara perlakuan penyaringan terhadap nilai kandungan logam $\mathrm{Fe}$ dan $\mathrm{Cu}$ (Gambar 5) serta NAF (Gambar $6)$.

Pada Gambar 5 dan 6 dapat dilihat bahwa sampel minyak awal memiliki nilai kandungan logam $\mathrm{Fe}$ dan $\mathrm{Cu}$ sebanyak 76 ppm dan 24 ppm serta kandungan NAF sebesar 126 ppm . Berdasarkan hasil proses penyaringan diketahui setiap kali proses penyaringan cenderung menurunkan nilai kandungan logam $\mathrm{Fe}$ dan $\mathrm{Cu}$ serta NAF minyak.

Terjadinya penurunan kandungan logam setelah penyaringan karena adanya kandungan lignin, selulosa, dan hemiselulosa dalam TKKS. Lignin merupakan grup polimerfenol multi fungsional yang mengandung gugus hidroksil, karboksil dan karbonil (Dizhbite et al., 1999). Proses adsorbsi melibatkan adanya kandungan lignin, selullosa, dan adanya gugus fungsi karboksilat dan hidroksi dalam biosorben (Munaf et al., (1998). Ion dalam larutan akan terikat pada biosorben dan menggeser ion yang sama tandanya. Bila larutan ion dialirkan pada suatu bioadsorben maka ion hidrogen adsorben bertukar dengan kation, dan ion hidroksi bertukar dengan anion. 


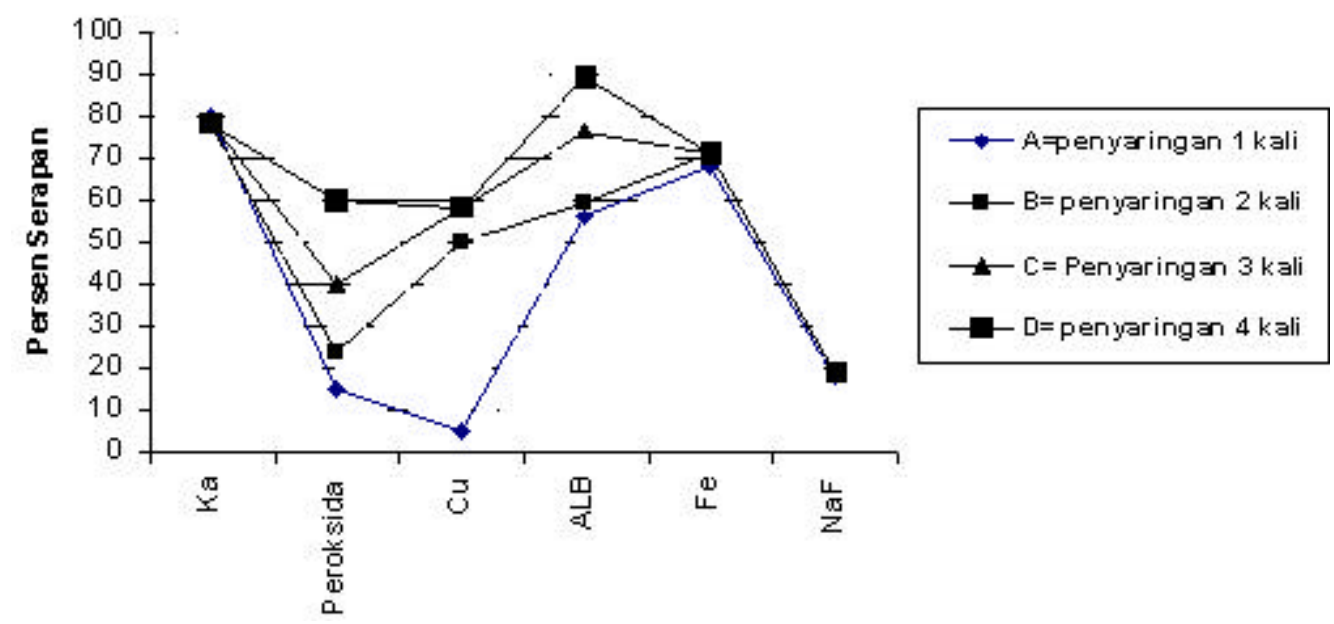

$\mathrm{Ka}=$ Kadar Air $\quad \mathrm{Cu}=\operatorname{logam} \mathrm{Cu} ; \quad \mathrm{ALB}=$ Asam Lermak Bebas; $\mathrm{Fe}=$ Logam Fe; NAF = Non urea Adduct Forming

Gambar 7. Serapan bioadsorben terhadap mutu minyak setelah penyaringan berulang.

Menurut Ketaren (1986) selama proses penggorengan terjadi reaksi pembentukan warna, rekasi oksidasi yang diikuti dengan polimerisasi dan reaksi hidrolisis dengan adanya air dari bahan yang digpreng. Oksidasi yang terjadi selama penggorengan menyebabkan terjadinya pembentukan peroksida yang tidak stabil dan mengalami dekomposisi lebih lanjut membentuk berbagai aldehid, keton, hidrokarbon, asam, dimer, timer, dan epoksida. Salah satu senyawa tersebut adalah NAF (Non-urea Adduct Forming).

\section{Serapan biosorben}

Serapan kadar air dari perlakuan penyaringan berkisar antara $78 \%$ sampai $80 \%$, serapan bilangan peroksida antara $14.71 \%$ sampai $59.80 \%$. Serapan asam lemak bebas antara $56.61 \%$ sampai $89.25 \%$. Serapan logam Fe dan $\mathrm{Cu}$ sebanyak $68.42 \%$ sampai $71.05 \%$ dan dari $5 \%$ sampai $58 \%$. Serapan NAF berkisar antara $17.46 \%$ sampai $19.05 \%$ (Gambar 7).

Penyaringan berulang meningkatkan serapan sifat fisiko-kimia minyak (Gambar 7). Terjadinya serapan ini selama penyaringan disebabkan adanya kandungan lignin, selulosa dan hemiselulosa pada bioadsorben TKKS melalui proses adsorbsi. Penggunaan bioadsorben TKKS dalam penyaringan minyak jelantah ini termasuk kedalam proses adsorbsi antara cairan dan padatan. Proses adsorbsi yang terjadi bisa secara fisik dan secara kimia. Kedua metode ini terjadi bila molekulmolekul dalam fase cair diikat pada permukaan suatu fase padat sebagai akibat dari gaya tarik menarik pada permukaan padatan (bioadsorben), (Cheremisin off and Moresi, 1978 in Winarno, 1999; Gu et al., 1994). Jika gaya tarikan antara molekul terlarut dengan molekul-molekul pelarut lebih kecil dari gaya tarikan antara molekul terlarut dengan bioadsorben maka zat terlarut dapat teradsorbsi. Penyaringan berulang akan mengakibatkan semakin lama terjadinya proses adsorbsi tersebut.

Menurut Munaf et al. (1998), proses adsorbsi melibatkan adanya kandungan lignin dan selulosa pada bioadsorben. Proses adsobsi oleh bioadsorben disebabkan adanya kandungan polisakarida dan polimer lain dalam sel. Dinding sel tanaman juga dibentuk oleh hemiselulosa yang mengandung gugus hidroksil dan karboksilat (Fengel and Wegener, 1995). Penyerapan oleh bioadsorben dipercayai terjadi melalui proses adsorbsi yang melibatkan adanya kandungan lignin, selulosa dan gugus hidroksil. Gugus hidroksil dan karboksilat dalam bioadsorben berperan dalam penyerapan ion logam (Refilda et al., 2000). Menurut Munaf and Zein (1997) bioadsorben dengan ukuran partikel yang kecil akan menyerap ion logam lebih banyak. 
Penyaringan sampai tiga kali menghasilkan minyak yang belum memenuhi standar mutu berdasarkan SNI-3555-1998. Tetapi penyaringan minyak sampai empat kali telah dapat menghasilkan minyak yang memenuhi standar mutu ditinjau dari kadar air, bilangan peroksida dan kandungan asamn lemak bebas. Hal ini terjadi karena proses adsorbsi oleh bioadsorben terhadap senyawa organik dan senyawa anorganik yang terdapat didalam minyak semakin lama.

\section{KESIMPULAN}

Penyaringan sebanyak empat kali telah dapat menghasilkan minyak yang telah memenuhi SNI dari segi kadar air $(0.23 \%)$, bilangan peroksida $0.82 \%$ dan bilangan asam lemak bebas $0.23 \%$ serta dapat menurunkan kandungan logam Fe dari 76 ppm menjadi 22 ppm, Cu dari 1.2 ppm menjadi 0.40 ppm dan NAF dari 126 ppm menjadi 102 ppm.

Serapan biosorben terhadap kandungan kadar air berkisar $78-80 \%$, bilangan peroksida 14.71-59.80\%, asam lemak bebas dari 55.6189.25\%, logam Fe dari 68.42-71.05\%, logam $\mathrm{Cu}$ dari $5-58 \%$ serta NAF dari $17.46-19.05 \%$.

\section{SANWACANA}

Penulis mengucapkan terimakasih kepada Direktur Politeknik Pertanian Negeri Payakumbuh, Kepala Pusat Penelitian dan Pengabdian Masyarakat dan pihak-pihak yang telah memberikan fasilitas selama penelitian.

\section{DAFTAR PUSTAKA}

AOAC, 1995. Official Metods of Analysis of the AOAC. Inc., Arlington Virginia.

Desminarti, S dan Rahzarni. 2004. Pemanfaatan Biosorben Tandan Kosong Kelapa Sawit Sebagai Material Penyerap Warna dan logam CPO. Laporan Penelitian, Politeknik Pertanian Negeri Payakumbuh.

Dizhbite, T, G. Zakis, A. Kizima, E.Lazareva, G. Rossinskaya, V. Jurkjane, G. Telysheva, anD U.Viesturs. 1999. Lignin: a useful bioresource for the production of sorption active materials. J. Bioresource Technology 67:221-228.

Djatmiko, B dan S. Ketaren. 1985. Pemurnian Minyak Makan. Agroindustri Press, Jurusan Teknologi Industri Pertanian. Fateta. Bogor. Fengel, D dan D. Wegener, 1995. Kayu, Kimia, Struktur, Reaksi-Reaksi. Terjemahan. Gajah Mada University Press, Yogyakarta.

Gu, B., J. Schmitt, Z. Chen, L. Liang, and J. mcCarthy. 1994. Adsorption and desorption of natural organic matter on iron oxide: Mechanisms and models. Environ. Sci. Technol. 28(1): 38-46.

Ketaren, S. 1986. Minyak dan Lemak Pangan. UI Press, Jakarta.

Liener, I.E. 1980. Toxic constituent of plant food stuffs. Academic. Press Inc, New York.

Marlina, L. 1997. Toksikan dari Kontaminan. Program Studi Ilmu Pangan. Program Pascasarjana. IPB, Bogor.

Munaf, E and R. Zein. 1997. The use of rice husk or removal o toxic metals rom wastewater. Environ. Technol. 18:359-362.

Munaf, E, R. Zein, Refilda, Deswati, and V. Oktasari. 1998. Removal of phenol from hospital wastewater using manggis husk. J. Kimia Andalas, 4(2):111-117.

Rahzarni. 2003. Pembuatan biosorben tempurung kemiri dan pemanfaatannya untuk penanggulangan ion kadmium dan kromium dalam air limbah. Tesis. Program Pasca sarjana Universitas Andalas. Padang.

Refilda, E. Munaf, R. Zein, Deswati and E. Kayora. 2000.J. Ammonia biosorption characteristics of rice husk. J. Hayati (Biosains), 7:110-112.

Said, G. 1996. Penanganan dan pemanfaatan limbah kelapa sawit. Trubus Agriwidia. Unggaran. Jakarta.

Sarasbudhe, M.R and V.R. Bhalerao. 1963. A methode for determination of the extend of the polymerization in frying fats and in fats extracted from fried foods. JAOCS 40:711712.

Winarno, F.G. 1999. Minyak Goreng Dalam Menu Masyarakat. Pusat Pengembangan Teknologi Pangan. Institut Pertanian Bogor. Bogor. 